\title{
The Optimization of Crop Pattern for Maximizing The Irrigation Yield in Jatikulon Mojokerto
}

\author{
A Suhardono', S S Riskijah², H Kurniawan ${ }^{3}$ \\ \{agussuhardono66@gmail.com ${ }^{1}$,ririssafiatus@gmail.com² ${ }^{2}$,hendrykurniawan69@gmail.com ${ }^{3}$ \}
}

Politeknik Negeri Malang, Jl. Soekarno Hatta, No. 9, Malang, East Java, Indonesia 1,2,3

\begin{abstract}
There were problems to meet water demand in 431-hectare Jatikulon irrigation area in Mojokerto District from Brantas river. The purpose of this study was to obtain maximum irrigation yield in limited field under the dependable discharge constraint by Linear Programming. The variables are area of paddy, corn, and sugarcane. The constraints are dependable discharge and available irrigation area. The objective is to maximize irrigation yields. The optimization analysis reveals that the largest dependable discharge is $7121 / \mathrm{sec}$. The highest water demand for paddy, corn, and sugarcane are 2.487, 1.180, and $1.282 \mathrm{l} / \mathrm{sec} / \mathrm{ha}$ respectively. The designed crop plants are 62 ha paddy, 369ha corn, and 0 sugarcane in season I; 0 paddy, 356ha corn and 0 sugarcane in season II; and 0 paddies, 194ha corn, and 0 sugarcane in season III. The maximum profit in season I, II, and III are Rp.6,730,554,448, Rp 5,118,677,651, and Rp.2,790,580,427 respectively.
\end{abstract}

Keywords: dependable, discharge, crop pattern, maximum profit.

\section{Introduction}

Population growth is directly proportional to the increasing need for life. In order to meet increasing food needs, agricultural products must be increased by farmers. Agriculture is often associated with the presence of water, because the water needs of the land that are fulfilled also affect the growth of plants, and crop yields. then it is appropriate if every land there is an irrigation system that is useful for channeling plant water needs. The availability of irrigation water must be used effectively and efficiently so that more benefits can be taken. There is a need to regulate cropping patterns in irrigation areas so that the water needs of plants can be in accordance with availability.

The Jatikulon Irrigation Area in Mojokerto with an area of 431 hectares of water extracted from the Brantas River. The Jatikulon irrigation area has delayed irrigation water to meet the water needs of plants. From the three planting seasons in a year, it is known that farmers' land was not planted in the third period because of the availability of irrigation water that was not sufficient. This was found in the rice fields of the twin villages of Kweden, Kwatu, and Leminggir. This condition causes low agricultural yields[1].

The existence of these problems, it is necessary to optimize crop pattern, so that agricultural products increase and become maximal. Plants that are commonly planted by farmers in Mojokerto include paddy, corn, sugarcane. The results of the optimization are planned for optimum cropping patterns and in accordance with the availability of irrigation water. 
Based on the background and problems mentioned above, the objectives of this discussion include: Calculate dependable discharge available in the Jatikulon Irrigation, calculating the water demand of each plant, determine the pattern of planting systems based on the availability of irrigation water, calculating the maximum profit from agricultural products.

\section{Literature Review}

\subsection{Irrigation}

Irrigation is channeling water that is necessary for the growth of the soil plants that are processed and distributed systematically[2]. In order for irrigation water to be used effectively and efficiently, it is necessary to regulate cropping patterns. The cropping pattern is a way of regulating cropland use and plant species within a certain period of time. The purpose of setting a cropping pattern is to get the amount of irrigation water for plants on the land according to availability[3].

\subsection{Dependable Discharge}

Dependable discharge is the minimum flow of the river for prescribed fulfilled possibilities that can be used for irrigation. The probability of being fulfilled is set at $80 \%$ (the possibility that the river discharge is lower than the mainstay discharge is 20\%). River minimum discharge is analyzed on the basis of the river's daily debit data[4]. Calculation of the dependable discharge with the Basic Year Method, using equation (1)

$$
\mathrm{R}_{80} \quad=\frac{\mathrm{n}}{5}+1
$$

Information :

$$
\begin{array}{ll}
\mathrm{n} & =\text { number of observation periods (years) } \\
\mathrm{R}_{80} & =\text { the mainstay value with the possibility of being smaller than } \mathrm{R}_{80} \text { has a probability of } \\
& 20 \% \text {, while the one greater or equal to } \mathrm{R}_{80} \text { has a probability of } 80 \% .
\end{array}
$$

\section{3 irrigation water Demand}

Irrigation water demand is the amount of water volume needed to meet the needs of evapotranspiration, water loss, water requirements for plants by noting the amount of water supplied by nature through rain and groundwater contributions[5]. The planned discharge rate is influenced by Net field requirements, irrigated area, and channel irrigation efficiency.Irrigation water demand is calculated using equation (2)

water demand per hectare $=\frac{\text { NFR } \times A}{\mathrm{e}}$

Information :

NFR =net field requirements $(\mathrm{mm} /$ day $)$

A $\quad=$ area irrigated (ha)

e =irrigation efficiency

Efficiency in each plot is estimated as follows[4]

a. Water losses in tertiary channels are $15-22 \%$. The amount of irrigation efficiency ranges from $77.5 \%-85 \%$

b. The water loss in the secondary channel is $7.5-12.5 \%$. The amount of irrigation efficiency ranges from $87.5 \%-92.5 \%$ 
c. Water losses in the primary channel are $7.5-12.5 \%$. The amount of irrigation efficiency ranges from $87.5 \%-92.5 \%$

Calculationnet field requirements using equation (3)and equation (4)

$\mathrm{NFRpaddy}=\mathrm{Cu}+\mathrm{Pd}+\mathrm{P}+\mathrm{WLR}-\mathrm{Re}$

NFRcrops $=\mathrm{Cu}-\mathrm{Re}$

Information :

$\mathrm{Cu} \quad=$ plant water requirements $(\mathrm{mm} /$ day $)$

$\mathrm{P} \quad$ =water loss due to percolation $(\mathrm{mm} /$ day)

$\mathrm{Pd} \quad=$ land preparation needs $(\mathrm{mm} /$ day $)$

$\mathrm{Re} \quad=$ effective rainfall $(\mathrm{mm} /$ day $)$

WLR = replacement of standing water $(\mathrm{mm} /$ day $)$

\subsection{Crop Pattern Optimization}

Optimization is an attempt to determine the best solution from a number of alternatives with various constraints that exist on a model[6]. The analysis in this study uses linear programs because the use of linear programs has the following advantages:

a. This method can be used to complete the system by changing the constraint function sufficiently

b. This use is easy and accurate

c. The mathematical function is simple

Meanwhile, the limitations of this program are that they cannot analyze complex irrigation area systems. So it needs to be simplified in analyzing irrigation area system. Completion of optimization problems with linear programs begins by determining the decision variable that the optimum value wants to find. This mathematical model consists of two parts, namely:

1) Purpose Function

The purpose function is to maximize profits from land use with available water. Equation (5) for the following:

$\mathrm{Z}=\mathrm{C} 1 \mathrm{X} 1+\mathrm{C} 2 \mathrm{X} 2+\ldots+\mathrm{CnXn}$

Information :

$\mathrm{Z}=$ purpose function (maximum profit of agricultural produce) (Rp.)

$\mathrm{Cn}=$ net profit $(\mathrm{Rp} . / \mathrm{ha})$

$\mathrm{Xn}=$ area of irrigation (ha)

2) ConstraintsFunction

The constraint function is the equation of the amount of plant water needs which is limited by the availability of each planting period and area of each plant which is limited by total area. Equation (6), equation (7) and equation (8) for the following:

$\mathrm{a} 11 \mathrm{X} 1+\mathrm{a} 21 \mathrm{X} 2+\ldots+\mathrm{anmXn} \leq \mathrm{bm}$

$\mathrm{X} 1+\mathrm{X} 2+\ldots+\mathrm{Xn} \leq \Sigma \mathrm{X}$

$\mathrm{X} \geq 0$

Information :

$\mathrm{X}=$ area of irrigation (ha)

a = irrigation water demand (1/sec/ha)

$\mathrm{b}=$ dependable discharge $(1 / \mathrm{sec})$

$\mathrm{n}=$ number of decision variables

$\mathrm{m}=$ number of constraints 


\section{Method}

This method will be used as a reference in carrying out the stages of research so that the time provided can be utilized as optimally as possible[6].

a. Collect data. These data include intake discharge secondary channel, rainfall from Tampung, Sambiroto and Terusan stations of in 2008-2017, type of soil, climatology from KP Mojosari station in 2013-2017, profit analysis per hectare[7].

b. Conduct a literature study. The study was carried out both through irrigation books, planning criteria, and scientific journals.

c. Calculating dependable discharge. In the calculation using Jatikulon intake discharge.

d. Calculate the effective rainfall from rainfall data. And process climatology data into potential evapotranspiration data. by calculating plant coefficients and potential evapotranspiration that produce value for plant water needs.

e. Calculate water requirements for land preparation, change of water layer, and percolation.

f. Calculating the net field requirements that are influenced by effective rainfall, percolation, crop water requirements, cropping patterns and associated with irrigation efficiency data in the field then calculate the water demand per hectare.

g. Create a mathematical model of the water demand, Dependable Discharge, and the purpose of finding the maximum profit gained from each hectare of the plant to be planted.

h. Optimization using linear programs, and controls, if not ok back to planting plans and water demand per hectare.

i. The optimal cropping pattern is obtained, then find out what the maximum profit value is. and finished.

The sequence of research stages is illustrated in the following flow chart:

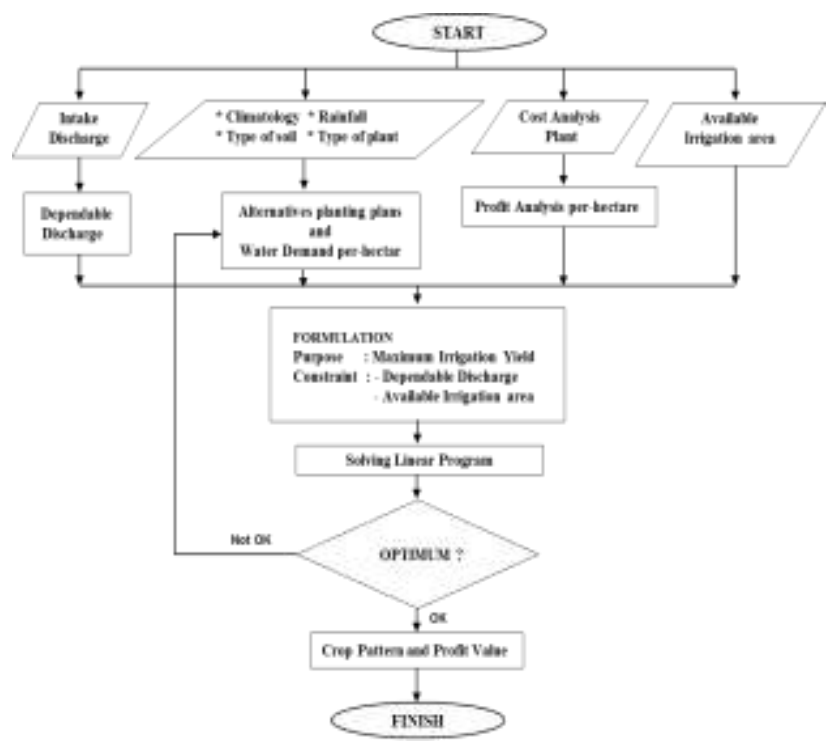

Figure 1. Research Completion Flow Chart 


\section{Result and Discussion}

\section{Dependable Discharge}

Calculation results dependable discharge using equation (1)

\begin{tabular}{|c|c|c|c|c|c|c|c|c|c|c|c|}
\hline \multicolumn{3}{|c|}{ November } & \multicolumn{3}{|c|}{ December } & \multicolumn{3}{|c|}{ January } & \multicolumn{3}{|c|}{ February } \\
\hline I & II & III & I & II & III & I & II & III & I & II & III \\
\hline 183 & 216 & 463 & 342 & 712 & 673 & 664 & 472 & 617 & 447 & 518 & 545 \\
\hline \multicolumn{3}{|c|}{ March } & \multicolumn{3}{|c|}{ April } & \multicolumn{3}{|c|}{ May } & \multicolumn{3}{|c|}{ June } \\
\hline I & II & III & I & II & III & I & II & III & I & II & III \\
\hline 360 & 554 & 481 & 349 & 328 & 315 & 234 & 334 & 436 & 429 & 402 & 455 \\
\hline \multicolumn{3}{|c|}{ July } & \multicolumn{3}{|c|}{ August } & \multicolumn{3}{|c|}{ September } & \multicolumn{3}{|c|}{ October } \\
\hline I & II & III & I & II & III & I & II & III & I & II & III \\
\hline 459 & 364 & 303 & 352 & 323 & 330 & 267 & 240 & 186 & 175 & 163 & 158 \\
\hline
\end{tabular}

\section{Irrigation Water Demand}

The planned discharge rate is influenced by net field requirements, irrigated area, and channel irrigation efficiency.[8]Calculation results of irrigation water demand using equation (2)

\begin{tabular}{ccccc}
\hline \multirow{2}{*}{ Month } & \multirow{2}{*}{ Period } & \multicolumn{3}{c}{ Water Demand (I/sec/ha) } \\
\cline { 2 - 5 } & & Paddy & Corn & Sugarcane \\
\hline \multirow{3}{*}{ November } & I & 2.487 & 0.067 & 0.123 \\
\cline { 2 - 5 } & II & 2.233 & 0.209 & 0.317 \\
\cline { 2 - 5 } & III & 1.772 & 0.250 & 0.332 \\
\hline \multirow{3}{*}{ December } & I & 1.543 & 0.423 & 0.420 \\
\cline { 2 - 5 } & II & 1.110 & 0.148 & 0.077 \\
\cline { 2 - 5 } January & III & 1.596 & 0.497 & 0.427 \\
\cline { 2 - 5 } & I & 1.482 & 0.471 & 0.410 \\
\cline { 2 - 5 } & II & 1.259 & 0.377 & 0.424 \\
\hline \multirow{3}{*}{ February } & III & 0.494 & 0 & 0.101 \\
\cline { 2 - 5 } & I & 0.497 & 0 & 0.362 \\
\cline { 2 - 5 } & II & 0.882 & 0 & 0.476 \\
\hline
\end{tabular}

Table2. Water Demanding Season I 


\begin{tabular}{ccccc}
\hline \multirow{3}{*}{ Month } & \multirow{2}{*}{ Period } & \multicolumn{3}{c}{ Water Demand (l/sec/ha) } \\
\cline { 2 - 5 } & & Paddy & Corn & Sugarcane \\
\hline \multirow{3}{*}{ March } & I & 1.139 & 0 & 0.286 \\
\cline { 2 - 5 } & II & 1.489 & 0 & 0.702 \\
\cline { 2 - 5 } & III & 1.243 & 0.008 & 0.669 \\
\hline \multirow{3}{*}{ April } & I & 1.383 & 0.342 & 0.727 \\
\cline { 2 - 5 } & II & 1.586 & 0.509 & 0.758 \\
\hline \multirow{3}{*}{ May } & III & 1.560 & 0.485 & 0.656 \\
\cline { 2 - 5 } & I & 1.722 & 0.658 & 0.791 \\
\cline { 2 - 5 } & II & 1.556 & 0.605 & 0.794 \\
\hline \multirow{2}{*}{ June } & III & 1.466 & 0.590 & 0.863 \\
\cline { 2 - 5 } & I & 1.221 & 0.278 & 0.795 \\
\cline { 2 - 5 } & II & 1.515 & 0.114 & 0.795 \\
\hline & III & 1.872 & 0 & 0.795 \\
\hline
\end{tabular}

Table 3. Water Demand in Season II

\begin{tabular}{ccccc}
\hline \multirow{3}{*}{ Month } & \multirow{2}{*}{ Period } & \multicolumn{3}{c}{ Water Demand (I/sec/ha) } \\
\cline { 2 - 5 } & & Paddy & Corn & Sugarcane \\
\hline \multirow{3}{*}{ July } & I & 0 & 0.046 & 0.972 \\
\cline { 2 - 5 } & II & 0 & 0.180 & 0.972 \\
\cline { 2 - 5 } August & III & 0 & 0.368 & 0.972 \\
\cline { 2 - 5 } & I & 0 & 0.692 & 1.141 \\
\hline \multirow{3}{*}{ September } & II & 0 & 0.851 & 1.141 \\
\cline { 2 - 5 } & III & 0 & 0.942 & 1.141 \\
\cline { 2 - 5 } & I & 0 & 1.180 & 1.282 \\
\hline \multirow{3}{*}{ October } & II & 0 & 1.092 & 1.171 \\
\cline { 2 - 5 } & III & 0 & 0.959 & 1.061 \\
\cline { 2 - 5 } & I & 0.444 & 0.541 & 0.902 \\
\hline & II & 1.331 & 0.221 & 0.517 \\
\hline
\end{tabular}

Table 4. Water Demand in Season III

\section{Crop Pattern Optimization}

The analysis in this study uses a linear program and steps taken first are interpreting the problems in the study area. 431-hectare Jatikulon irrigation area in Mojokerto. Based on the analysis of harvest profit, it is obtained from several sources with some adjustments to the unit price of Mojokerto area approved by agriculture service having following values: net profit of paddy per hectare per season Rp.22,895,000 and corn per hectare per season Rp.14,390,000. each planting season lasts approximately four months so that in one year there are three planting periods. While net profit of sugarcane per hectare per season or one year Rp. 
$38,332,000$. In order to get the same profit value every four months, the profit of sugar cane per hectare per season is divided by three so that the value of profit is Rp.12,777,333[2].

The purpose is to maximize irrigation yields. The decision variables specified are:

$\mathrm{X} 1$ =the area planted with paddy (ha)

$\mathrm{X} 2=$ the area planted with corn (ha)

$\mathrm{X} 3$ =the area planted with sugarcane (ha)

The constraints:

Alternative I : constraints are dependable discharge and available irrigation area.

Alternative II : constraints are dependable discharge and available irrigation area + existing sugarcane (55ha).

Alternative III : constraints are dependable dischargeand available irrigation area + increase supply sugarcane (110ha).

Formation of linear program formulations is made every planting season, according to the purpose and constraints of each season[1].

1. Formulation of linear program season I

Purpose function : Maximize $Z=22,895,000$ X1 + 14,390,000 X2 + 12,777,333 X3

Constraint function:

\begin{tabular}{|c|c|c|c|c|c|c|c|c|c|}
\hline 2.487 & $\mathrm{X} 1$ & + & 0.067 & $\mathrm{X} 2$ & + & 0.123 & $\mathrm{X} 3$ & $\leq$ & 183 \\
\hline 2.233 & $\mathrm{X} 1$ & + & 0.209 & $\mathrm{X} 2$ & + & 0.317 & $\mathrm{X} 3$ & & 216 \\
\hline 1.772 & $\mathrm{X} 1$ & + & 0.250 & $\mathrm{X} 2$ & + & 0.332 & X3 & & \\
\hline 1.543 & $\mathrm{X} 1$ & + & 0.423 & $\mathrm{X} 2$ & + & 0.42 & X3 & & 42 \\
\hline 1.110 & $\mathrm{X} 1$ & + & 0.148 & $\mathrm{X} 2$ & + & 0.077 & X3 & & \\
\hline 1.596 & $\mathrm{X} 1$ & + & 0.497 & $\mathrm{X} 2$ & + & 0.427 & X3 & & \\
\hline 1.482 & $\mathrm{X} 1$ & + & 0.471 & $\mathrm{X} 2$ & + & 0.41 & X3 & & \\
\hline 1.259 & $\mathrm{X} 1$ & + & 0.377 & $\mathrm{X} 2$ & + & 0.424 & X3 & & \\
\hline 0.494 & $\mathrm{X} 1$ & + & 0 & $\mathrm{X} 2$ & + & 0.101 & X3 & & \\
\hline 0.497 & $\mathrm{X} 1$ & + & 0 & $\mathrm{X} 2$ & + & 0.362 & $\mathrm{X} 3$ & & \\
\hline 0.882 & $\mathrm{X} 1$ & + & 0 & $\mathrm{X} 2$ & + & 0.476 & $\mathrm{X} 3$ & & \\
\hline 1.270 & $\mathrm{X} 1$ & + & 0 & $\mathrm{X} 2$ & + & 0.489 & $\mathrm{X} 3$ & & \\
\hline $\mathrm{X} 1$ & & + & $\mathrm{X} 2$ & & + & $\mathrm{X} 3$ & & & \\
\hline \multicolumn{6}{|c|}{ (addition of constraints alternative II) } & $\mathrm{X} 3$ & & & \\
\hline \multicolumn{6}{|c|}{ (addition of constraints alternative III) } & $\mathrm{X} 3$ & & & \\
\hline
\end{tabular}

$\mathrm{X} 1=62 \mathrm{ha}, \mathrm{X} 2$ = 369ha, X3 = 0ha, optimum results alternative I, Rp.6,730,554,448maximum profitalternative I.

$\mathrm{X} 1=59 \mathrm{ha}, \mathrm{X} 2=317 \mathrm{ha}, \mathrm{X} 3=55 \mathrm{ha}$, optimum results alternative II, Rp.6,617,023,693maximum profitalternative II.

$\mathrm{X} 1=56 \mathrm{ha}, \mathrm{X} 2=265 \mathrm{ha}, \mathrm{X} 3=110 \mathrm{ha}$, optimum results alternativeIII, Rp.6,503,492,938maximum profitalternative III.

2. Formulation of linear program season II

Purpose function : Maximize $Z=22,895,000 \mathrm{X} 1+14,390,000 \mathrm{X} 2+12,777,333 \mathrm{X} 3$

Constraint function :

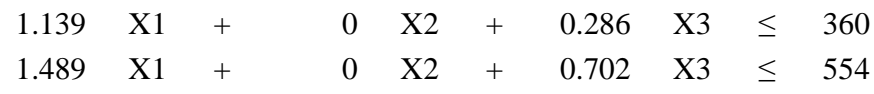




\begin{tabular}{|c|c|c|c|c|c|c|c|c|c|}
\hline 243 & $\mathrm{X} 1$ & + & 0.008 & $\mathrm{X} 2$ & + & 0.669 & $\mathrm{X} 3$ & $\leq$ & 481 \\
\hline 383 & $\mathrm{X} 1$ & 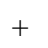 & .342 & $\mathrm{X} 2$ & & .727 & $\mathrm{X} 3$ & 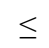 & 349 \\
\hline 586 & $\mathrm{X} 1$ & + & .509 & $\mathrm{X} 2$ & & 0.758 & 3 & . & 328 \\
\hline 60 & $\mathrm{X} 1$ & + & 0.485 & K2 & & 566 & $\mathrm{x} 3$ & & 315 \\
\hline 722 & $\mathrm{X} 1$ & + & 0.658 & $\mathrm{X} 2$ & + & 0.791 & X3 & - & 234 \\
\hline 556 & $\mathrm{X} 1$ & + & .605 & $\mathrm{X} 2$ & & 0.794 & $\mathrm{x} 3$ & & 334 \\
\hline 466 & $\mathrm{X} 1$ & + & 0.590 & $\mathrm{X} 2$ & + & 0.863 & X3 & $\leq$ & 436 \\
\hline 221 & $\mathrm{X} 1$ & + & 0.278 & $\mathrm{X} 2$ & & 0.795 & $\mathrm{X} 3$ & ك & 429 \\
\hline 1.515 & $\mathrm{X} 1$ & + & 0.114 & $\mathrm{X} 2$ & $T^{T}$ & 0.795 & $\mathrm{X} 3$ & $\leq$ & 402 \\
\hline 1.872 & $\mathrm{X} 1$ & + & 0 & $\mathrm{X} 2$ & + & 0.795 & $\mathrm{X} 3$ & $=$ & 455 \\
\hline $\mathrm{X} 1$ & & + & $\mathrm{X} 2$ & & & X3 & & $\leq$ & 431 \\
\hline \multicolumn{6}{|c|}{ addition of constraints alternative II) } & $\mathrm{X} 3$ & & & 55 \\
\hline \multicolumn{6}{|c|}{ addition of constraints alternative I } & $\mathrm{X} 3$ & & & 110 \\
\hline
\end{tabular}

$\mathrm{X} 1$ = 0ha, $\mathrm{X} 2$ = 356ha, $\mathrm{X} 3$ = 0ha, optimum results alternative I, Rp.5,118,677,651maximum profit alternative $\mathrm{I}$.

$\mathrm{X} 1$ = 0ha, X2 = 290ha, X3 = 55ha, optimum results alternative II, Rp.4,869,220,762maximum profit alternative II.

$\mathrm{X} 1=$ 0ha, $\mathrm{X} 2=223 \mathrm{ha}, \mathrm{X} 3=110 \mathrm{ha}$, optimum results alternative III, Rp.4,619,763,873maximum profit alternative III.

3. Formulation of linear program season III

Purpose function : Maximize $Z=22,895,000 \mathrm{X} 1+14,390,000 \mathrm{X} 2+12,777,333 \mathrm{X} 3$

Constraint function :

\begin{tabular}{|c|c|c|c|c|c|c|c|c|c|}
\hline 0 & $\mathrm{X} 1$ & + & 0.046 & $\mathrm{X} 2$ & + & 0.972 & X3 & $\leq$ & 459 \\
\hline 0 & $\mathrm{X} 1$ & + & 0.180 & $\mathrm{X} 2$ & + & 0.972 & X3 & $\leq$ & 364 \\
\hline 0 & $\mathrm{X} 1$ & + & 0.368 & $\mathrm{X} 2$ & + & 0.972 & $\mathrm{X} 3$ & $\leq$ & 303 \\
\hline 0 & $\mathrm{X} 1$ & + & 0.692 & $\mathrm{X} 2$ & + & 1.141 & $\mathrm{X} 3$ & $\leq$ & 352 \\
\hline 0 & $\mathrm{X} 1$ & + & 0.851 & $\mathrm{X} 2$ & + & 1.141 & X3 & $\leq$ & 323 \\
\hline 0 & $\mathrm{X} 1$ & + & 0.942 & $\mathrm{X} 2$ & + & 1.141 & X3 & $\leq$ & 330 \\
\hline 0 & $\mathrm{X} 1$ & + & 1.180 & $\mathrm{X} 2$ & + & 1.282 & X3 & $\leq$ & 267 \\
\hline 0 & $\mathrm{X} 1$ & + & 1.092 & $\mathrm{X} 2$ & + & 1.171 & X3 & $\leq$ & 240 \\
\hline 0 & $\mathrm{X} 1$ & + & 0.959 & $\mathrm{X} 2$ & + & 1.061 & X3 & $\leq$ & 186 \\
\hline 0.444 & $\mathrm{X} 1$ & + & 0.541 & $\mathrm{X} 2$ & + & 0.902 & X3 & $\leq$ & 175 \\
\hline 1.331 & $\mathrm{X} 1$ & + & 0.221 & $\mathrm{X} 2$ & + & 0.517 & X3 & 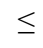 & 163 \\
\hline 2.219 & $\mathrm{X} 1$ & + & 0 & $\mathrm{X} 2$ & + & 0.148 & X3 & $=$ & 158 \\
\hline $\mathrm{X} 1$ & & + & $\mathrm{X} 2$ & & + & X3 & & $\leq$ & 431 \\
\hline \multicolumn{6}{|c|}{ (addition of constraints alternative II) } & $\mathrm{X} 3$ & & $=$ & 55 \\
\hline \multicolumn{6}{|c|}{ (addition of constraints alternative III) } & $\mathrm{X} 3$ & & & 110 \\
\hline
\end{tabular}

$\mathrm{X} 1$ = 0ha, X2 = 194ha, X3 = 0ha, optimum results alternative I, Rp.2,790,580,427maximum profit alternative $\mathrm{I}$.

$\mathrm{X} 1=$ 0ha, X2 = 133ha, X3 = 55ha, optimum results alternative II, Rp.2,617,997,354maximum profit alternative II.

$\mathrm{X} 1=0$ ha, $\mathrm{X} 2$ = 72ha, X3= 110ha, optimum results alternative III, Rp.2,445,414,282maximum profit alternative III. 
Results from the analysis and calculation of the three alternatives, the greatest benefit value if applying alternative I. The designed crop plants is 62 ha paddy, 369 ha corn, and 0 sugarcane in season I; 0 paddy, 356ha corn and 0 sugarcane in season II; and 0 paddy, 194ha corn and 0 sugarcane in season III.Rp.6,730,554,448 maximum profit in season I, Rp.5,118,677,651 maximum profit in season II, Rp.2,790,580,427 maximum profit in season III.

\section{Conclusion}

Based on the results of analysis and calculations

a. The largest dependable discharge is $712 \mathrm{l} / \mathrm{sec}$ in December.

b. The highest water demand for paddy, corn, and sugarcane are $2.487,1.180$, and 1.282 1/sec/ha respectively.

c. The designed crop plants are 62 ha paddy, 369ha corn, and 0 sugarcane in season I; 0 paddy, 356ha corn and 0 sugarcane in season II; and 0 paddies, 194ha corn, and 0 sugarcane in season III.

The maximum profit in season I, II, and III are Rp.6,730,554,448, Rp 5,118,677,651, and Rp.2,790,580,427 respectively. The story spread around the island in Indonesia, giving another conclusion, could be the story represent man's behavior toward a woman in order to attract a woman's heart.Robi in Wibowo [9]found that it is possible JakaTarub's Story and Tanaba have the same characters, plot and setting even though Indonesia and Japan located in the far distance. According to Lévi-Strauss [9], the similarity of the story (in Indonesia and Japan), is

\section{References}

[1] S. F. Yanuar, "Optimasi Jaringan dan Evaluasi Dimensi Saluran Primer Irigasi Bangsalsari,” Pros. Sentrinov 2017 ISNN2477-2097, vol. 3, 2017.

[2] K. T. dan Suyono Sosrodarsono, Hidrologi untuk Pengairan. Jakarta: PT. Pradnya Paramitha., 2003.

[3] M. Bardan, Irigasi. Yogyakarta: Graha Ilmu., 2014.

[4] D. P. Dep. PU, "Standar Perencanaan Irigasi, Kriteria Perencanaan Bagian Jaringan Irigasi," KP-01, 2010.

[5] S. K. Sidharta, Irigasi dan Bangunan Air. Jakarta: Guna Darma., 1997.

[6] R. Broson, Teori dan Soal-soal Operations Research. Jakarta: Erlangga., 1996.

[7] A. Suhardono, "Optimasi Penggunaan Lahan Pertanian dengan Program Linier (Lokasi Studi JI Sumber Buntu, Kecamatan Jabung, Kabupaten Malang),” J. Tek. Pengair., vol. 2, no. 1, pp. 55-61, 2012.

[8] D. Pengairan, "Bina Program PSA," 1985.

[9] R. Wibowo, "Jaka Tarub dan Tanabata: Kajian Strukturalisme Levi-Strauss," 2013. 